\title{
A Revisit to COVID-19 Challenges and Responses: A Case Study of Kerala
}

\author{
Norvy Paul, ${ }^{+*}$ Elsa Mary Jacob ${ }^{\hat{\imath}}$ and Sheena Rajan Philip
}

\begin{abstract}
Kerala, a state with high development indices distinguished with its Kerala Model of Development (UN, 1975), is also affected by recent Pandemic COVID'19 as other states and nations worldwide. The existing socioeconomic analysis of the State reveals that the land reforms, promotion of education, and early introduction of participatory governance through Panchayati Raj Institutions (PRIs) have contributed to the State's socioeconomic and political advancement. These factors played a significant role in the fight against the pandemic. This study is an attempt to answer what are the future economic and health challenges as the State, Kerala Model of Development, is faced with COVID'19? The specific objectives further guide this - to study the economic challenges ahead of the State as the tertiary sector is faced with challenges to contribute to the economy and attempted to study the possible ways to address health issues in the State. The researchers conducted an in-depth interview among10 social scientists and economists of Kerala using purposive sampling to obtain primary data, which has been supported by secondary resources. The researchers did a thematic analysis of the primary data collected, further corroborated by secondary data. The study reveals that the State's current scenario during the pandemic, the grass-root empowerment in all spheres of life clubbed with administrative guidance, resulted in well-equipped public health care service delivery. The fall in the tertiary sector's income has decisively affected the State's economy, especially in agriculture, health, IT, tourism, labour, and foreign remittance. The State's economic and social equilibrium will face challenges in addressing issues in the post-COVID era. Even though the State suffered some increased Covid-19 cases recently, after expatriates' return, the dimensions mentioned above assisted the State in its fight against COVID'19. To address the challenges to the Kerala Model of Development, especially the post-COVID-19 requirements of the State demands interrogation, introspection, and integration of the current policies that majorly depend on the tertiary sector and initiate policies, plans, and programmes to strike a balance between all sectors, especially providing impetus to the primary sector so that a failure in one sector can be compensated by the other.
\end{abstract}

Keywords: COVID'19 Challenges; Resilient Rebuilding Challenges; Kerala; India

\footnotetext{
${ }^{+}$Senior Lecturer in Social Work, The Catholic University of Eastern Africa, Nairorbi.

${ }^{*}$ Corresponding Author, Email: frnorbypaul@gmail.com

îAssistant Professor in Social Work, BMC, Cochin, Email: els.joe@gmail.com

${ }^{¥}$ Assistant Professor in Social Work, BMC, Cochin, Email: sheenaphilip07@gmail.com

(C) 2020 Paul et al. This is an Open Access article distributed under the terms of the Creative Commons Attribution License (http://creativecommons.org/licenses/by/2.0), which permits unrestricted use, distribution, and reproduction in any medium, provided the original work is properly cited.
} 


\section{Introduction}

Kerala inhabits a narrow strip of land on the southwest coast of India, $580 \mathrm{~km}$ in length, and $30.130 \mathrm{~km}$ in breadth, bounded to the west by the Arabian Sea and the east by the Western Ghats. Kerala was divided into three areas; Travancore and Cochin were princely states while Malabar was part of the Madras Presidency under colonial rule. The Western Ghats marginally separate the land from the mainland of India. Kerala has long been a major international trading centre. The State is abundant and evenly distributed resources have fostered an even pattern of settlement that has simplified health and educational service delivery. Kerala's achievements rest on several factors; several historical eras obligate fetched about some of the world's highest standards of health, education, and social justice (Kennedy, Robin, and Zamuner, 2013). Before the 19th century, Kerala society was a passive receiver of inequality, discrimination, and caste oppression (Rebuild Kerala Initiative- Government of Kerala. (n.d), 2019). The norms set by each caste system determined the status of the individual in society and divided society into several groups based upon ascription within which mobility was impossible (School of Distance Education, 2011). The role of religion in social integration refers to three points (1) the relations between different castes and religious groups at the village and other local levels, (2) the general role of religion in the economic development of the country; and (3) religion and socio-economic privileges (Prakash, 2017). There is an association between religious communities and the specific economic functions they perform. The spread of various communities worldwide and the diversification of their economic activities have strengthened social integration. The Prevalence of structural inequalities also invited the attention of missionaries who came to work in Kerala (V T \& Lullit, 2013). With the missionaries' help, the East India Company established schools in different Malabar and admitted students regardless of castes and creed. The colonial authorities' political and administrative policies on land (Ryotwari principle of Richard in 1803, ${ }^{1}$ Malabar Tenancy Act of 1929) ${ }^{2}$ and other areas also helped bring radical changes in the rigid caste structure (Kositsky, 2009). Along with missionary activities, the new nationalist movements arose in the early 20th Century, namely the Indian National congressKozhikkode Conference (1904) and Vaikom Satyagraha (1924-25), conscientiesed the people fostering social development, and Kerala witnessed social and cultural advances in the following decades. This paper therefore is making an attempt to deliberate on what the socio-historical background of the Kerala as a state that facilitated the growth Kerala Model of Development, the transition process happened in the later years in addressing various crisis faced in the state. Though the state stands unique in its social indices the economic crisis of the state demands to thinking of alternatives or way forwardness. Often the state depended on tertiary sector for its economic resources but COVID'19 has affected the sector's performance. This invites the people and administrative system to find alternatives to address the crisis which deems possible by reflecting on various contributing factors of the state's economy and achievement of Kerala Model of Development.

\section{Background}

Kerala is a state which has become a successful, replicable model for its development since 1980s. The discussions on how Kerala advanced socially, economically and politically revolves around the development chronicles which

\footnotetext{
${ }^{1}$ It is a system followed in British India to collect land revenue from cultivators. Instead of appointing mediators to collect land revenue, the British Rulers in India imposed the land revenue upon cultivators and directed to pay directly by the individual cultivators who actually worked the land) and the system of assessment was known as Ryotwari.

2 The Act was an attempt to the fixity of tenure on cultivating tenants (verumpattomdars) after paying fair rent to the government. Under this act, the intermediaries like Kanomdars and Kuzhikanomdard play a crucial role in fixing land rent based on three categories of land: wetland, garden land, and dry land. These intermediaries also influence of renewal of the land rent yearly. The renewal norm was fixed on the revenue received from the land.
} 
deserves mention even today. The social and political advancement gradually led Kerala into joining the mainstream of political struggle for freedom and the formation of responsible governments in the 20th Century (Government of Kerala, 2020). This catalysing change's critical outcome was the awakening of the masses, especially the lower orders in the Hindu society, against social injustice and evils. The awakening found its manifestation in Kerala towards the last quarter of the 19th Century. Several socioreligious reform movements motivated people to voice out against the then-prevailing caste system that existed in a heinous way where the lower orders were considered 'untouchable' and "unapproachable".

As part of the national agenda of rural renovation, Kerala is one of the few Indian states that implemented land reforms, namely the Restriction on Possession and Ownership of Lands Bill, 1954, Kerala Agrarian relations bill, 1957, ${ }^{3}$ Kerala Land Reforms Act 1963. ${ }^{4}$ These policies refer to endeavours by the Government to accomplish social equivalence and optimum utilisation of land by reallocating the landholdings (Prakash, 2017) against the previous practice of the privileged few holding large acres of land and the peasants were exploited for their labour and wages. Through these policies, Kerala Government was committed to redistribution of land to the tillers. After the independence Malabar Tenancy (Amendment) Act 1954 afforded fixity of tenure to all cultivating verumpattakars (tenants without right). Kerala Agrarian Relations Bill of 1957 and Kerala Land Reforms Act of 1963

\footnotetext{
3 Agrarian Relations Bill introduced on 18th December 1957 to achieve the goal of land reforms in Kerala provided a uniform system of agrarian relation throughout Kerala. It is one of the unique model of social transformation and agricultural development. The Bill provided provisions for tenancies and possession of land to the tenants from the landlords (Chandran, 2018).

${ }^{4}$ Kerala land reforms Act of 1963 and later amended and came into force on 1 January 1970 was the one which put an end to the feudal system and transferred the ownership of land to the tenants. This proved a major landmark in eradicating food insecurity and alleviating rural poverty in Kerala.
}

which later amended in 1969 were the legislations which eliminated landlordism in the State of Kerala. These reforms are also intended to rearrange farmers' relationship to land to achieve a democratic social structure, eliminate exploitation and social injustice, and provide security for the tiller of the soil, thereby enlarging the rural poor's land base and increasing productivity. The ownership conferred on tenants acted as an incentive to increase output. This, augmented by the Green revolution, ${ }^{5}$ contributed to growth in the agricultural sector (Radhakrishnan, 1983).

Both socio-cultural and political movements and land reforms have transformed the sociocultural landscape of Kerala (livemint. n.d) A shift of cultivation from food crops to cash crops met its climax with the introduction of the liberalisation policies in the 1990s. However, the new economic reforms did not provide trade openings in the international market as expected as the country entered into the General Agreement on Tariff and Trade (GATT). ${ }^{6}$ As a result, the importers found alternatives, which led to a recession in the agricultural sector. Subsequently, a middle class emerged who did not consider land a primary source of livelihood but invested their energy in the political, economic, and educational sectors, causing a transition (Scaria, 2010). "Kerala's current agricultural life faces the question why after 64 years of its formation [in]1956, Kerala depends on states of Andhra Pradesh for rice, Tamil Nadu for vegetables, and Karnataka for meat? Can such a society base on external dependence on food, to such an extent, be considered a model?"

\footnotetext{
${ }^{5}$ Green revolution is the enhancement of agricultural technology transfer adopted mainly by developing countries to increase the production of agricultural produces especially rice and wheat by using high yielding varieties (Encyclopaedia Britannica).

${ }^{6}$ The General Agreement on Tariffs and Trade came into force on 1 January 1948 is a legal agreement between many countries, whose overall purpose was to promote international trade by reducing or eliminating trade barriers such as tariffs or quotas and eventually leading to the creation of the World Trade Organization (WTO) on 1 January 1995, which absorbed and extended it. By this time, 125 nations were signatories to its agreements, which covered about $90 \%$ of global trade (Majaski, 2019).
} 
(Balakrishnan, 2008; Parapurath, 2018). It urged the State to relook the reforms, which resulted in promoting agriculture, retaining land rights, and legalising collective farming on fallow land (Kallungal, 2019).

The origins of Kerala's high public investments in areas such as health care and education can be traced back even during the British rule. The presence of Christians in Kerala compelled the missionaries to work in the State, supported by British India Administration, that provided Christian missionaries grants to build schools in the region. Local administrative policies boosted this. By 1904, the Government of Travancore had already begun to take up the entire cost of primary education for lower caste residents and making a share of public education expenditure of Travancore $18 \%$ by the year 1924-25 (Shah, 2010). The church also played an essential role in raising resources for low-income families to pay for education. Much of Kerala's educational financing, during and after Indian independence, came from private funds raised through collective mobilisation. The elected State Government's thrust on education also gave impetus to establish educational institutions remain the main reason behind Kerala's high literacy rate (Shah, 2010; Jeromi, 2003). The story of Kerala's public health achievements is similar in some ways to its educational success. Kerala had made tremendous progress in its medicare system, which contributed to the high health status. Travancore and Cochin's rulers had implemented Western-style health care systems starting in the 19th Century (Shah, 2010). The emergence of private health service delivery also went hand in hand with the public service system, which made thee medicare facilities in Kerala comprising an excellent network of institutions of various medicine streams - Allopathic, Ayurveda, Homeopathic, Siddha, Unani (Sharma, 2020).

\section{Transition of Kerala}

The State's economy predominantly focused on the primary sector, agriculture (Jeromi, 2003), until new economic reforms and gradually made transition to the tertiary sector (Singla, 2017). It is worthy to note that the State showed remarkable progress in its human development index as Kerala invested much earning from its agrarian sector on human development, which paved the way for a smooth transition from this primary agricultural sector to the tertiary service sector (Shah, 2010). The rise in living standards and social mobility influenced by western ideology and culture sabotaged the agricultural sector; instead, it remained within and retained by the very few. Thus production came down drastically, leaving this minority with the burden of feeding the rest with a substantial initial investment and minimal gains.

The growth in Kerala has been uneven and disproportionately driven by growth in the service sector. This transition has been witnessed through structural changes during the 1960s through the present (Singla, 2017). Kerala Model was portrayed as an alternative path for human development by development experts and western academics because during its course of action, a robust welfare system rather than economic growth drove social progress. (Pillai, 2008). Dirigiste policies explain how a highly educated, healthy society has been unable to achieve robust economic growth despite substantial latent capacities. Kerala's female literacy rates were higher than any single province in China, and by1999, life expectancy for males and females in Kerala was 74 years, one year more than in South Korea, four years more than China, and 11 more than India overall (Revidrandran., 2020). Kerala's service economy, income in the State effectively stagnated over the last decade. The size of Kerala's service sector is more extensive than Gujarat's industrial and agricultural sectors combined. The Kerala model is proof of a unique mix of high human development and low per-capita income and consumption indicators (Ministry of Finance, Government of India, 2019). It was something perplexing to the development and economic experts that even though the State's commodity produce was weak, the State achieved commendable indices in social domains such as adult literacy, infant mortality, birth rate, and life expectancy (State Planning Board, 2018). However, it augmented the structural inequalities like the gap between the rich and 
the poor, marginalisation, unequal production and consumption patterns, and unequal distribution of resources.

Further, it questioned local sustainability and self-reliance as the State majorly relied on the global economy for essential commodities. Kerala's most extensive poverty eradication programme (Kudumbasree Mission) has gained worldwide attention and applause to facilitate empowerment at the grassroots level. This has focused the social and political empowerment beyond its primary economic dimension. It raised critical consciousness at the grass-root level as people are well aware of their rights (Jemal, 2017). Though the primary objective of the uplifting grass-root economy and local sustainability has set the scene for this project, it partially failed to address these areas in its implementation process (BMSSW KOCHI, 2020). The country's economic development approach favouring capitalist economies also contributed to this plight. Instead of generating more employment opportunities, it deprived India of accessing the essentials during the COVID outbreak (Nair, 2020).

Over the last two years, even though the State has faced economic setbacks due to natural disasters and recessions in the national and international economies that severely affected the remittance flows, the State survived these setbacks through its tertiary service sector transactions (Shaijumon, 2020). The sectors that catalysed economic growth were fishing and aquaculture, trade and manufacturing, hotel industry, education, health, real estate, information technology, and tourism. These structural changes can probably be attributed to State's strengths - Kerala's socio-economic and cultural capitals. Cultural capital refers to the collection of symbolic elements such as skills, tastes, posture, clothing, mannerisms, material belongings, credentials, etc. that one acquires through being part of a particular social class. Sharing similar forms of cultural capital with others creates a sense of collective identity and group position ("people like us"). According to Bourdieu, cultural capital comes in three forms-embodied, objectified, and institutionalized (Bourdieu, 1993). Socioeconomic and cultural capitals contributed to this tremendous growth and development (Government of India, 2019; Arya \& Watts, 2018).

This background is very pertinent in the pandemic crisis that the State's incomegenerating tertiary sector witnessed a contraction mode during and after lockdown. Kerala State Planning Board estimated that Kerala had been hit by a loss of INR 800000 millions amidst coronavirus lockdown 2020 (State Planning Board, 2018). The structural inequalities which remained unchanged during the growth process (Kumar and Yasir, 2017) made the State and its subjects more vulnerable during the pandemic crisis. This is because corona hit was not locality or class-specific; instead, it had hit the entire population cutting across geographical and cultural boundaries. The focus on the economic dimension has also got the rationale in State's responsibility to cater to the needs of a large segment of approximately 143147 emigrants who have returned in the backdrop of the pandemic, losing their livelihoods (Expats rush to Kerala, 2020). There is a broad cross-section of the existing population whose economic pursuits are standstill in the pandemic attack. Though the State had taken measures to repatriate migrants to their hometowns, there is still a significant number working in the unorganised sectors. Even though the State has succeeded in flattening the corona outbreak curve initially, fighting an economic crash would be a mightier task to handle. Considering these, the State's economic burden to meet its welfare and raise its indices requires strategic planning and implementation (Shaijumon, 2020).

Agriculture plays a prominent and unavoidable role in a country's economy and food security system, but the unprecedented COVID-19 pandemic has adversely affected agriculture, resulting in large income losses for agricultural institutions in the public sector and every citizen's quality of life (State Planning Board, 2018; Pothan, 2020). The economists forecasted that the Indian economy would be utterly ailing 
due to the pandemic, and according to the International Monetary Fund, the largest economy badly hit by the pandemic is India (International Monetary Fund, 2020). It will have its massive wrecks on human life. This colossal economic crash world population faces leaving them in deprivation of basic needs, is crucial.

Furthermore, these massive blows have affected the small State of Kerala too. Tax revenues are set to crash, and India's relatively stable debt-toGDP ratio is most likely to be spiked up to $90 \%$. In its attempts to contain and battle the virus, the State can deplete its resources, subsequently pressuring the citizens in its rebuilding journey. The control for the spread of this virus can bleed the state resources and put the Government in pressure to take additional steps to heal the economic washout, which can be an extra burden to the citizens, especially during this malady (Sharma, 2020).

\section{Material and Methods}

The researchers depended on an in-depth interview (over the phone) to collect the primary data from 10 participants selected purposively. The study participants were social scientists and economists, academicians, and practitioners with ten years of experience with a doctoral degree. The participants include 3 Social Workers (P.1, P.2 \& P.3), 3 Sociologists (P.4, P.5 \& P.6), 2 Economists (P.7\& P.8), 1 Historian (P.9), and 1 Political Scientist (P.10) who were selected randomly but fulfilled criteria living in the State of Kerala. Individual names of the participants of the interview are withheld and mentioned as P1, P2, P3...P10. The researchers used in-depth interviews via telephonic medium in the vernacular language (Malayalam) to collect data and the interviews were recorded with the consent of the participants. The recorded data were transcribed and then translated into English and the same is given to language expert to verify the quality of the translation. The transcripts were analysed for emerging themes and interpretation (Creswell, 2007). The researchers attempted to identify future economic and health challenges as the State is faced with COVID'19. The specific objectives that guide this study is to:
- understand the role of education and social and cultural advancement and contributive factors in the development of State;

- to study the economic challenges ahead of the State as the tertiary sector is faced with challenges to contribute to the economy, the possible way forward to address health issues in the State.

The researchers conducted a thematic analysis of the primary data collected. The primary data were then corroborated by secondary data, and presented below.

\section{The Trajectory of Development}

Since its inception, the State has been formulating long term visions of welfare and development tried and tested through the fiveyear plans. These five-year plans witnessed various development approaches: welfare approach, community development approach, decentralisation approach, participatory development approach, and inclusive development approach, which have been reinforced by the participants.

The early social reforms and education movement by Christian missionaries has contributed to the advancement of the state, and the communist government has also contributed to such status, especially by bringing land reforms (P.1).

Social movements led by Sree Narayanaguru, Chattabi Swami are an evident example of such social advancement (P.10).

This social advancement promoted Kerala's education and social capital, irrespective of people's economic status (Swain, 2004).

The substantial influence of Gulf remittances since 1973 in alleviating poverty was also a contributing dimension since the 1980s which are being demonstrated by the following narratives:

The opportunities for gulf migration helped the economy grow, and people had money to improve quality of service and consider District of Malapuram at 
least one of the family members was working in Gulf Countries (P.5).

As the income sources increased, the demand for quality of services increased and also the implementation of Panchayath Raj and women reservation was another boost to advancement of the state (P.6).

The Government allocated $40 \%$ of its annual budget for development projects as part of Panchayati Raj Institutions (PRI) implementation. This had given due weightage to projects designed by local bodies under people's movement - Janakeeya Kootayma. ${ }^{7}$ Here, the contribution of social capital during the contours of development witnessed by the State cannot be disregarded.

It is also imperative to state that the development process was not a progressive and steady one, as far as the State of Kerala is concerned:

The New Economic Reforms opened job openings in the service sector and preference for white-collar jobs seen (P.7).

The option for tertiary sector challenged the primary section (P10).

The far-reaching structural changes underwent by the agrarian economy, coupled with prolonged economic stagnation and decelerating growth and the State's perceived inability to generate employment opportunities to its subjects, were lessons reflected by the policymakers and governance specialists. The educated unemployment created in the State with the disruption of the primary sector was among the contingencies that coaxed Middle Eastern migration (Prakash, 1998). Nevertheless, this, by all means, turned out to be positive in developing Kerala's economy in no time.

Introspection into Kerala's cultural capital poses a second thought about whether cultural capital

\footnotetext{
'Jenakeeya Kootayma (Peoples' movements) implies a movement spearheaded by people where people define their development, where people are their own agents of change unlike bureaucratic NGOs and where people
}

rooted in values, norms, traditions, goals (collective habits and aims), and social life has more say in supporting Kerala's economy be flourished over time. Could cultural capital foster and nurture over the period have prevented these economic and social crises that we encounter today? It should be reiterated that self-promoted and sustained socio-cultural advancement and political awareness created a high development index that is rational and efficient since it released the people's suppressed energies. Perhaps, sociologists and economists reinforce more in understanding Kerala's Model of development: the educational and social advancement promoted by volunteerism and the well-established public health delivery system, advancements in the tertiary health sector after 1991, which signify and support the concept of the welfare state. As one of the participants narrated:

The volunteer service seen in recent days is really the mark of Kerala, and nowhere we can find in the country, and perhaps this makes our state unique (P.5).

The bureaucratic machinery that is very responsive to the pressures and demands of the organised groups and local political mobilisation has to be well acknowledged in social and economic transformation scenarios. It proved to be a leading element even during the toughest blows the State faced in three consecutive years - two devastating floods in 2018 and 2019 and the pandemic crisis which we are facing now. This idea has been reinforced by one of the participants who argued:

Though people in Kerala advanced in par with developed nations, the cultural capital of the State still powerful and evident in recent flood and even COVID'19 responses. This is the very uniqueness of Kerala (P.10).

This idea corroborates the study of (Swan, 2004). The well-established and efficiently monitored

challenge the structures of oppression, and where people create a political space for themselves (Bhattacharya, 2012). 
Public Distribution System proved viable in addressing the demand for basic needs even when the public budget ran on the deficit (Cyriac, Sam and Jacob, 2008). Kerala's publicdistribution system is aided by an umbrella of several other chains of retail shops run by the Government and the state cooperative sector that cover the length of the State (Joseph, 2020). A recent study by Centre for Socio-Economic and Environmental Studies discloses that Keralites relied heavily on the public distribution system to survive the COVID-19-induced lockdown. It states that $92 \%$ of the households made purchases from ration shops during the lockdown, and $16 \%$ of visited ration shops during the lockdown after a long gap (Subsidy Category), and $85 \%$ of the non-priority category, made purchases using their ration cards during the lockdown (Martin, 2020). Hence, even when the world faces this pandemic crisis, Kerala stands at the forefront, making policy reforms with decisions to concentrate and incorporate the primary sector, accelerating agricultural production, ultimately focusing on better quality of life (Shaijumon, 2020).

It poses the question of striking a balance between the sectors and keeping local actions that respond to global needs. This demands shedding unproductive political and social concepts and depend on positivism that addresses local needs. A reorientation of development priorities and welfare administration is required in the post COVID era. This has also been raised by the participants:

COVID'19 challenged our economic life and destabilised. The service sectororiented employment pattern may not be able to address the economic crisis and what is required is the reorientation of the employment pattern (P.6).

The state authority has to focus on economic and social policy revising and strategies to boost agriculture has to be undertaken (P.7).

It cannot materialise stand-alone economic sustainability. Culturally moulded strategies that can impel the current employment priorities and welfare service delivery have to be incorporated.
Self-sustained development priorities, indigenously reflected and developed within the cultural and social frameworks, adapted to the pandemic's challenge, have to be devised and implemented. It demands a bottom-up approach guided by top-down knowledge, skill, and strategies learned from past successes and failures. As one of the participants argue:

Government has to give thrust to the primary sector, and it is not the absence of resources and will power, but a conducive environment that promotes initiatives is missing in Kerala (P.7).

This should ensure people's issues first, and then social and political issues ensue. As a selfcontained state, Kerala has ample possibilities in the way forward with meticulously formulated and implemented policies and projects tapping its own technological and human resources to become economically self-reliant and sociopolitically advanced.

\section{Resilient Rebuilding (Back to Nature) Challenges.}

This lockdown in Kerala history has paved the way for reconstructing the governing system to curb the issue based on disaster management and crisis intervention policies. The Government of Kerala took the initiative for "active surveillance, setting up of district control rooms for monitoring, capacity-building of frontline health workers, risk communication and strong community engagement, and addressing the psychosocial needs of the vulnerable population are some of the key strategic interventions implemented by the state government that kept the disease in control" World Health Organisation (https://www.who.int/) has been pointed out by one of the participants.

The initial intervention strategies and action plans initiated by government and thrust gave to public health system show the remarkable progress of state to combat COVID'19 (P.3).

The decisions to strengthen the public health care service delivery by equipping and constructing State-owned hospitals to nurse the sick, providing food for stranded migrant 
workers through community kitchen, supplying food through public distribution system irrespective of income status, delivering food and medicines to the vulnerable, and sick at doorsteps, initiating vegetable cultivation in homesteads, promotion of cultivation in the fallow land demanded administrative changes that required policy and plan changes but initiated by Government of Kerala to address COVID'19 challenges. Policies and plans to ensure local sustainability and economic developments are still under discussion (Shaijumon, 2020). Added to the pandemic's adverse effect, the food insecurity marked on Kerala natives is alarming and highly thoughtprovoking. This thought has been reflected by one of the research participants.

The food dependency on other states of the country is challenging because there is no adequate cultivation of Kerala's food crops, especially vegetables and paddy. The lockdown has increased the price of food items, and hoarding is reported in many places. This will be another challenge of the Government to provide food at an affordable price, which demands the promotion of selfsufficient oriented agriculture, including homestead and dryland cultivation (P.5).

The excellent and secure access to food from the homeland in Kerala's case is very scarce due to lack of inland agriculture and cultivation and over-dependence on the neighbouring states for the supply of grains, crops, and vegetables the daily use. The situation is worst in the Covid-19 outbreak. The pressing need for food and food security is increasing, and the vocation towards the "Agri-culture" is beckoning the natives of Kerala. Though the State is able to have a buffer stock of food grains during the lockdown, it has prompted Keralite to till their land and start cultivation. This will realise the reverse of food security to economic security. Dodging of agriculture completely for other kinds of income generation keeps the less privileged or the rest states' food supply and security duty. Imposing food supply on the rest and focusing on industrial and technological development and advancement in Kerala and working solely for these two sectors securing more money with less time became a trend among Keralites.

A post-lockdown shortfall in essential commodities has prompted a relook at farming patterns. Today Kerala is on the verge of heeding to the need and signs of the time to establish food security and life (Muringatheri 2020). Migrant workers from Bengal, Orissa, and Tamil Nadu are even ready to work in agriculture as they are paid higher as compared to their home state. They all have left the haven, and the whole land is left behind without the workforce to farm and challenges to work for livelihood. Except for the government officials and bureaucrats, none has permanent income and safety for work due to the pandemic explode. This can initiate food security and, at the same time, contribute much to a healthy economy. It has proved that agriculture has turned out to be a safe zone and activity in most difficult situations and crises, which has also been resonated by one of the participants.

Food security is not only the business of Government or farmers but of each one of us. We need to look for alternatives, including organic and healthy food crops. The challenge is to bring down the preference for spending time and make a habit of cultivating for daily living (P.5).

There are several kinds of significant and promotable agricultural habits starting from rooftop gardens, grow bag gardens, micro vegetable gardens to macro-level of agriculture, and high yielding crops that could support the economic stability and food security system of a nation. This needs to be incorporated and supported by the promotion of social capital that promotes neighbourhood relationships encouraging each one in their endeavour, and the Government shall formulate and implement policies of the culture of self-dependent agriculture. A transition from a cyclic process of the industrial and money-oriented lifestyle into the agrarian and life sustenance with food security and economic stability will facilitate a treading back to the lost culture. 


\section{Transition: The Way Forward}

Kerala development had been characterised by structural transformation from primary agricultural sector to tertiary service sector which catalysed Kerala's economic development in a rapid manner. But this transition to service sector and the development impacts after that had adversely affected after the pandemic crisis as service sector has been crashed after the pandemic. Local self-reliance and sustainability were overlooked in the light of development prospects. When Covid-19 slammed into Kerala's ordinary lives, the efficient supply chain management and the market economy were affected. The participants of the study during the data collection mentioned about alternatives to sustain the economy. A reverse transition and transformation back to primary agricultural sector coupled with technological advancements promoting local self-reliance has to take place to face the challenges of today's economic and health challenges.

The pandemic has lessened the economic activities, and money circulation in the market became less, and cash available to the common man for daily living became limited. We need to think of alternatives that sustain us and even become exporters of food and commodity (P.7).

Lockdown restrictions have plunged people into hunger and starvation as borders were shut, and economic processes have come to a grinding halt. If Kerala had not side-lined the primary sector during its development, we could have been more stable and poised in this global crisis.

As the government is promoting selfsustained agriculture, it has also to promote massive production using highlevel innovative technology, and this not only boosts the economy but also lessens the unemployment and overdependency on the tertiary sector which is one of the causes of the economic crisis of the state (P.8).

This needs to be incorporated and supported by promoting social capital that promotes neighbourhood relationships that encourage each one in their endeavour. The Government shall formulate and implement policies of selfdependent agriculture. This transition and transformation should incorporate modern technologies to revive agriculture, including Artificial Intelligence (Al) and robotics. Expert discussions have even brought out the possibilities of adopting the Israel model in boosting agriculture. Having posed these arguments, there remains a need for thoughtful investments to transfer and transform the existing challenges brought by the Covid-19 pandemic into great opportunities. The brain drain that happened during the last decades has to be tapped and constructively promoted as State faces the burden of exorbitant unemployment rates and has the responsibility to support its large number of immigrants. A well-educated workforce now back in their homeland has to be employed in data mining and analytics domains. This will help Kerala stand par with developed technologies embracing the new advancements for a globalised yet self-sustainable economy. Revenue generation should take a new turn in promoting Micro, Small, and Medium Enterprises (MSMEs), and Kerala has to embrace the model of remote working.

Promotion of agriculture investment, creating an environment of agriculture promotion, strengthen the information technology and agri-informatics, promotion of higher education in agriculture, promotion of investment incentives and loans, strengthening of agriculture marketing and branding, enacting laws and enforcement of policies that strengthen new ventures in agriculture both food crop and cash commodities have to be initiated if the state wants to balance all sectors (P.10).

A positive sign of this realisation is evident in the State. The Government has to invest in providing essential facilities to promote it substantially. In rebuilding, the State has initiated the Subhiksha Keralam project envisaging locally self-reliant and sustainable communities. It claims as a 
comprehensive programme aimed at enabling and ensuring Kerala's food security is implemented through local self-government. Setting apart a 38600 million budget, almost 25 000 hectares of fallow land will be utilised for cultivation. The project aims to build self-reliant communities, increase production, and enhance the economy and attitudinal changes by investing one's potential in agricultural pursuits. Another initiative by the government Vyavasaya Bhadratha' plans to assist MSMEs with 34.34 billion in the post-pandemic period. This will support 156000 enterprises in the State. Lockdown and its ramifications have surged the usage of virtual learning platforms around the world. The State stands high in literacy rates rendering quality education seen as one of the strengths in its development, adapting to the upcoming needs in the educational sector requires a skill-based education policy. Kerala stepped into the hospital industry as part of its course of development in the tertiary sector and has established an efficient tertiary health care system with structured linkages with the primary and secondary sectors. The accessibility of health services to the general public is managed by the well-efficient decentralised public health delivery system. As one of the research participants' state:

As the reverse brain drain happens, the technical expertise has to be made to address the challenges in the health sector. Since the State has health services, both private and public, the State has to promote both small and medium companies and organisations in parallel. What is required in creating a healthy atmosphere that promotes investment both in traditional and modern medicine (P.4).

This service industry foresees excellent prospects in building the Kerala economy through high-end diagnostics, biotechnology, and medical devices (Post-COVID, Kerala Offers Good Business Potential, 2020). This will automatically generate employment opportunities. The decisive action at the policy level would facilitate the enhancement of employment opportunities. This requires a change in the mind-set of the policymakers; capitalism with compassion should be the approach, and Kerala has to transform from God's own country to technology's own country. Kerala has a slew of socio-economic, cultural, and political factors that helped the State fight the crisis. These factors serve as unique strengths in the rebuilding process as well. The State's responsible citizens, critical consciousness and political participation, competitive democratic culture, responsive and efficient governance, well-entrenched public health delivery, and decentralised strategies make the Kerala model a globally replicable and appreciable one.

A trajectory in the self-sustained or selfdependent economy, a thrust that integrates primary with secondary and tertiary sectors, is possible when the right acknowledgement of social, political, and cultural capital is realised. The economic and social advancement in par with development indices is realised only in this State where other states of the country remained developing status due to its capital advancement. The ability to convince, integrate and implement culturally fit and socially advanced and politically awakened policies and programmes for the society that deep-rooted in the self-sustained principles like peoples' participation and facilitation for investment that never doom with political crisis instigated by trade unionism but bloom to be boon to state. It can mark its commencement with individual and community cultivation integrated with technology simplified and amplified by government facilitation for better marketing. The question is how we integrate the reverse brain-drain in the development practice aiming at a self-sustained economy. The underutilised and unutilised human resource has to be reckoned while programme and project are designed, but value-oriented integration of social and cultural capitals has to be criteria for justification development paradigms of post epidemic way forwardness. 


\section{Conclusion}

Kerala being a model of development, can find its uniqueness in education and health indices that stemmed from coming of missionary interventions both during local kings' rule and British rule passed to Government reaching a gradual transition from the agricultural sector to tertiary sector is evident in this model. The formation of the State gave great impetus to the welfare administration of the State as compared to other states of the country. As a state, it has a community ideology intertwined with social, political, and cultural capitals strengthened governance from 1956 from its inception, followed by revolutionary changes in land laws, labour laws, educational reforms, and economic development strategies. Recent floods and COVID'19 poised challenges to welfare administration due to its economic deficit. In the post-COVID-19 scenario, the State faces the dire need to administer its welfare services to fulfil its welfare State's mission. The gradual transition from the primary sector to the tertiary sector compelled the state machinery to depend on other states during COVID ' 19 for food products. The commitment to the State's welfare initiated strengthening and sustaining the quality of agriculture and allied service delivery. This can create less dependency on outsiders and develop alternative resources to address the economic deficit that emerged due to the poor performance of the service sector. Developing alternatives to overcome economic deficit of the state demands removing overstress to the tertiary sector and providing ample opening to the primary sector so that a balance between all the sectors is promoted by an inclusive development approach, guided and directed by social, economic, cultural, and political capitals. It is not dubious that the post-COVID-19 requirements of the state demand interrogation, introspection, and integration of all sectors to strike a balance between all sectors, especially providing impetus to the primary sector, so that the other sectors of the State can compensate a failure in one sector.

\section{References}

Arya, K.R., Watts, S. (2020). A study of poorly designed economic reforms in India. Journal of Critical Reviews, 7(4), 565-571.

http://jcreview.com/fulltext/197-

1585041009.pdf?1585744171

Balakrishnan, Pulapre (2008, May 17).

Imagining an Economy of Plenty in Kerala.

Economic and Political Weekly, 43(20),14-16.

https://www.epw.in/journal/2008/20

Bhattacharya, N., \& Jairath, V. (2012). Social

Movements, 'Popular' Spaces, and

Participation: A Review. Sociological Bulletin, 61(2), 299-319.

http://www.jstor.org/stable/23620969

BMSSW KOCHI. (2020, June 8). Bharathion International webinar series Day 4 (Video). YouTube, https://www.youtube.com/watch?v=TRnvP0Jt3 g8

Boudieu, P. (1993). Forms of Capital. In Handbook of Theory and Research for Sociology of Education. New York: Greewood Press.

Chandran, P.B.P.(2018). Kerala Agrarian relation Bill, 1957: An Analysis. Online Journal of Multidisciplinary Subjects, 12(1), 837-842.

http://www.researchguru.net/volume/Volume \%2012/Issue\%201/RG94.pdf

COVID-19: Study estimates Rs $80,000 \mathrm{cr}$ loss to Kerala economy. (2020, May 11). Outlook.

https://www.outlookindia.com/newsscroll/covi d19-study-estimates-rs-80000-cr-loss-to-keralaeconomy/1830548

Creswell, W.J. (2007). Qualitative Inquiry and Research Design Choosing among five approaches. Sage Publications

Encyclopedia Britannica (Ed.). Encyclopaedia Britannica.

https://www.britannica.com/event/greenrevolution

Encyclopedia. (n.d). Kerala Model of development.

https://www.encyclopedia.com/international/e ncyclopedias-almanacs-transcripts-andmaps/kerala-model-development 
Expats rush to Kerala; officials fail to set up quarantine facilities. (2020, June 26).

Mathrubhumi.

https://english.mathrubhumi.com/news/kerala /expats-rush-to-kerala-officials-fail-to-set-upquarantine-facilities-1.4860915

Government of Kerala (2020). Socio-Religious Reform Movement.

https://kerala.gov.in/reform-movement

Government of Kerala. (2019). Government of Kerala, Rebuild Kerala Development programme: A Resilient Recovery Policy Framework and Action Plan for Shaping Kerala's Resilient, Risk-Informed Development, and Recovery from 2018 Floods.

https://impactkerala.com/sites/default/files/DR AFT_RKDP_12_March_2019.pdf

International Monetary Fund. (2020, April). World Economic Outlook, April 2020: The Great Lockdown.

https://www.imf.org/en/Publications/WEO/Issu es/2020/04/14/weo-april-2020

Israeli technology to transform Indian agriculture. (2017, November 22). The Economic Times.

https://economictimes.indiatimes.com/tech/int ernet/israeli-technology-to-transform-indianagriculture/articleshow/61752914.cms

Jemal, A. (2017). Critical Consciousness: A Critique and Critical Analysis of the Literature. The Urban Review, 49(4), 602-626. https://doi.org/10.1007/s11256-017-0411-3 Jenny, R. (Ed.). (2002). Development and Displacement. Open University Press \& Oxford University Press: Milton Keynes.

Jeromi, D.P. (2003, April 19). What Ails Kerala's Economy: A Sectoral Exploration. Economic and Political Weekly. https://www.jstor.org/stable/4413463?seq=1

Joseph, T. A. (2020, April 26). How Kerala is feeding its 3.48 crore residents, migrants amid the COVID-19 lockdown. The Caravan. https://caravanmagazine.in/economy/keralasroadmap-to-feeding-its-348-crore-residentsmigrants-amid-the-covid-19-lockdown
Kallungal, D. (2019, September 30). One big farm: A detailed look at Kerala's agriculture scenario. The New Indian Express.

https://www.newindianexpress.com/states/ker ala/2019/sep/30/one-big-farm-a-detailed-lookat-keralas-agriculture-scenario-2041074.html

Kennedy, L., ROBIN K., Zamuner D. (2013, June 13). Comparing State-level policy responses to economic reforms in India. Regulation Review. http://journals.openedition.org/regulation/102 47

Kumar, S. A., \& Yasir, P. (2017). An inquiry into the dynamics of inequality from the perspective of Caste. Inequality, Poverty, and Development in India. DOI: 10.1007/978-981-10-6274-2_4

Livemint. (n.d). A short history of Indian economy 1947-2019: Tryst with destiny \& other stories.

https://www.livemint.com/news/india/a-shorthistory-of-indian-economy-1947-2019-trystwith-destiny-other-stories1565801528109.html

Majaski, C. (2019, October 24). General Agreement on Tariffs and Trade (GATT). Investopedia.

https://www.investopedia.com/terms/g/gatt.as $\mathrm{p}$

Martin, K.A. (2020, May 23). Keralites relied heavily on PDS during lockdown, says study. The Hindu.

https://www.thehindu.com/news/national/ker ala/keralites-relied-heavily-on-pds-duringlockdown-says-study/article31660893.ece

Ministry of Finance, Government of India. (2019). Economic Survey 2018-19.

https://www.thehindubusinessline.com/econo my/budget/article28281079.ece/binary/Econo micSurveyVolumell.pdf

Muringatheri, Mini. (2020. May 10).

Agribusiness to offer new opportunities postCOVID. The Hindu.

https://www.thehindu.com/news/national/ker ala/agribusiness-to-offer-new-opportunitiespost-covid/article31552634.ece

Nair, Naveen. (2020, March 29). COVID-19 Could Cripple Kerala's Economy Like Never 
Before. The lede.

https://www.thelede.in/kerala/2020/03/29/cov id-19-could-cripple-keralas-economy-like-neverbefore

Pillai N., Vijayamohanan. (2008). Infrastructure, growth, and human development in Kerala.

Munich Personal RePEc Archive.

https://mpra.ub.uni-muenchen.de/7017/

Post-COVID, Kerala offers good business potential. (2020, July 23). Business line. https://www.thehindubusinessline.com/news/ national/post-covid-kerala-offers-goodbusiness-potential/article32173196.ece\#

Prakash, A. B., (2017). Changes in Agrarian Structure and Land Tenures in Kerala: $A$ Historical Review. Thiruvananthapuram Economic Studies Society.

http://keralaeconomy.com/admin/pdfs/A\%2OH istorical\%20Review.pdf

Prakash, B. (2020, May 1). What Kerala paid for being Indias model COVID State. The Times of India.

https://timesofindia.indiatimes.com/india/what -kerala-paid-for-being-indias-model-covidstate/articleshow/75178569.cms

Prakash, B. A., (1998). Gulf migration and its economic impact the Kerala experience.

Economic and Political Weekly. http://keralaeconomy.com/admin/pdfs/two\%2 Oim.pdf

Ravindranathan, P. (2020, April 10). Covid-19: Kerala Model is the success of decentralised democracy. Policy Circle. https://www.policycircle.org/opinion/covid-19kerala-model-is-the-success-of-decentraliseddemocracy/

Rebuild Kerala. (n.d). Kerala Rebuild Initiative. https://rebuild.kerala.gov.in/en/about\#: :text= The\%20Government\%20established\%20the\%20 Rebuild,the\%20restructured\%20assets\%20coul d\%20better

Riser-Kositsky, Sasha (2009). The Political Intensification of Caste: India Under the Raj. Penn History Review,17(1). 3

Scaria, Suma (2010) Changes in land relations: The political economy of land reforms in a
Kerala village. Economic and Political Weekly, 45 (26\&27): 191-198

School of Distance Education, University of Calicut. (2011). Indian Society and Social Change.https://moodle.bhu.edu.in/pluginfile.p $\mathrm{hp} / 333 / \mathrm{mod}$ resource/content/2/Introduction \%20to\%20Indian\%20Society\%20.pdf

Serageldin, I. (1995). Nurturing Development: Aid and Cooperation in Today's Changing World. Washington, DC: World Bank.

Shah, A., (2010). Putting the 'Kerala Model' to Rest: Lessons for a New Era of Development in India. DOI:10.2139/ssrn.1680001

Shaijumon, C. S. (2020, April). COVID-19 and its Economic Impacts in Kerala. Kerala Calling, 1921. Public Relations Department, Government of Kerala

Sharma, M. (2020, June 26). View: India's economy is ailing from more than Covid-19. The Economic times.

https://economictimes.indiatimes.com/news/e conomy/indicators/view-indias-economy-isailing-from-more-than-covid-

19/articleshow/76637162.cms?from $=\mathrm{mdr}$

Shinoj, P. (2018, February 24). Agriculture Performance and Future Outlook on Food Commodities in Kerala. Agricultural Economics Research Review, 28, 247-258. DOI: 10.5958/0974-0279.2015.00040.3

Singla, Naresh, S. V. (2017). Structural transformations in Kerala's economy is there any role of agriculture sector? Journal of Regional Development and Planning. 5(2), 4558.https://www.researchgate.net/publication/3 13845245

Sirianni, C., \& Friedland, L. (n.d.). Social Capital, Civic Practice Network.

http://www.pn.org/tools/dictionary/capital.ht $\mathrm{ml}$

State Planning Board. (2018). Economic Review 2018.

http://spb.kerala.gov.in/ER2018/index.php

Swain, A. (2004). Social Networks and Protest Movements: The Case of Kerala. In D. Bhattacharya (Ed.). Interrogating Social Capital: 
The Indian Experience (pp. 298-310). New Delhi: Sage Publication.

V.T. Lankina, Lullit, G. (2013). Competitive religious entrepreneurs: Christian missionaries and female education in colonial and postcolonial India. British Journal of Political Science, 43(1), 103-131.

View: India's economy is ailing from more than Covid-19. (2020, June 26). The Economic Times. https://economictimes.indiatimes.com/news/e conomy/indicators/view-indias-economy-isailing-from-more-than-covid-

19/articleshow/76637162.cms?from $=\mathrm{mdr}$

\section{Conflict of Interest}

We certify that we have no affiliations or involvement with any organisation or entity bearing any financial interest (such as honoraria; educational grants; participation in speakers' bureaus; membership, employment, consultancies, stock ownership, or other equity interest; and expert testimony or patentlicensing arrangements), or non-financial interest (such as personal or professional relationships, affiliations, knowledge or beliefs) in the subject matter or materials discussed in this manuscript.

\section{Acknowledgements}

The authors humbly acknowledge the assistance and guidance extended to us to draft this article. Dr Venkat Pullla who has guided throughout the journey to draft this article, the editor and his team who provided us with a space to publish this article, participants of in-depth interviews who wholeheartedly provided primary data, and the reviewers of the article.

\section{About the Authors}

Norvy Paul (MSW, PhD, PDF) is an academician, whose research focus is on displacement with particular interest on social and cultural capitals, marginalisation, human rights and displacement. He did his PhD in Displacement and Social Capital and Post-Doctoral Studies in Displacement and Marginalisation. He has authored and edited seven books; published several articles in various national and international journals and presented papers. Currently, he is a Senior
Lecturer and Research Supervisor in Social Work in the Catholic University of Eastern Africa, Nairobi, Kenya.

Elsa Mary Jacob (MSW, PhD) is a professional social worker with more than a decade experience in the various fields of professional social work. She is currently working as an Assistant Professor at Bharata Mata School of Social Work, Bharata Mata College, Kochi, Kerala, India. Her research interests include adolescents and youth, women and skill development. Her contributions to the knowledge base of the social work profession includes action research and a number of publications and also has secured ICSSR fellowship.

Sheena Rajan Philip (MSW, PhD) claims 10 years' experience as an academician in social work and heads the Bharata Mata School of Social Work. She holds $\mathrm{PhD}$ in community development. $\mathrm{Dr}$ Sheena is a social scientist involved in social impact assessment in development initiatives taken by Governments. Her interested areas of research are slum development, sustainable development, and disaster management. Her expertise and immense experience in working with women towards their empowerment is commendable.

\section{Author Contribution Statement}

Norvy Paul, as the corresponding author of the article, confirm the following contributions of each author to draft this research article.

Norvy Paul (corresponding author): conceptualisation, methodology, Review and Editing

Elsa Mary Jacob (second author): Conducting empirical research and visualization Transcription, Translation and Analysis, Developing the first draft

Sheena Rajan Philip (third author): Literature Review, curation of data, developing the first draft; alongside editing and reviewing. 